\begin{tabular}{|l|l|l||}
\hline \multicolumn{2}{|c|}{ PublisherInfo } \\
\hline \hline PublisherName & $:$ & BioMed Central \\
\hline \hline PublisherLocation & $:$ & London \\
\hline \hline PublisherImprintName & $:$ & BioMed Central \\
\hline \hline
\end{tabular}

\title{
Ocular Immunology
}

\begin{tabular}{|l|l|l||}
\hline \multicolumn{2}{|c|}{ ArticleInfo } \\
\hline \hline ArticleID & $:$ & 19 \\
\hline \hline ArticleDOI & $:$ & $10.1186 /$ ar-2000-2-webreport0015 \\
\hline \hline ArticleCitationID & $:$ & 0015 \\
\hline \hline ArticleSequenceNumber & $:$ & 15 \\
\hline \hline ArticleCategory & $:$ & Web Report \\
\hline \hline ArticleFirstPage & $:$ & 1 \\
\hline \hline ArticleLastPage & $:$ & 3 \\
\hline \hline & & RegistrationDate : 2000-9-11 \\
\hline ArticleHistory & $:$ & OnlineDate \\
\hline ArticleCopyright & $:$ & Current Science Ltd2000-11 \\
\hline \hline ArticleGrants & $:$ & \\
\hline \hline ArticleContext & $:$ & 130752211 \\
\hline \hline
\end{tabular}




\section{Overview}

The Massachusetts Eye and Ear Infirmary (MEEI), one of the leading centers for both research and treatment of autoimmune eye diseases, administers this site.

\section{Content}

The site includes a "web" journal, 'Clinical Ocular Immunology'. Each month, a different topic is covered in the form of treatment algorithm, clinical review or study results. Topics of interest to rheumatologists include Treatment Algorithm for Juvenile Rheumatoid Arthritis-associated Iridocyclitis, Retinal Vasculitis: its Significance, The Severity of Episcleritis and Systemic Disease Association, and Ocular Manifestations of Systemic Lupus Erythematosus.

Laboratory research from the MEEI is also summarized on the web site. There is a section entitled MD Information, summarizing conferences and original articles by the medical staff. Topics covered include multiple autoimmune disorder, Behçet's Disease, Wegener's granulomatosis, discoid lupus, and the antiphospholipid antibody syndrome.

There is also a large selection of informational articles for patients. Minutes of their Uveitis Support Group is available online. The Ocular Immunology Discussion Group is an online forum that alows physicians and non-physicians to post questions, which may be answered by the MEEI faculty.

\section{Evaluation}

This web site is extremely helpful for the rheumatologist, allowing easy access to information on a wide variety of ocular problems encountered in the practice of Rheumatology. 


\section{References}

1. Ocular Immunology. [http://www.uveitis.org/Enhanced/index.htm]

This PDF file was created after publication. 